\title{
CONTENTS.
}

\author{
Vol. XI, No. 2.
}

PAGE

Portrait: Professor Ch. Joyeux, Marseilles ... Frontispiece

1. SOuthwel., T. Helminthology in its Applications to Marine Fisheries

2. Clapham, P. A. On the Life-History of Heterakis gallina ...

3. Thapar, G. S. On a New Trematode of the Genus Astiotrema

Looss, 1900, from the Intestine of a Tortoise, Chitra

$\begin{array}{llllllllll}\text { indica } & . . & \ldots & \ldots & \ldots & \ldots & \ldots & \ldots & \ldots & \ldots\end{array}$

4. Solomon, S. G. On a New Species of Enterobius from the Marmoset (Callithrix jacchus) $\quad \ldots \quad \ldots \quad \ldots \quad \ldots \quad \ldots$

5. Solomon, S. G. A Note on a New Species of Breinlia from a $\begin{array}{lllllllll}\text { Kangaroo } & \ldots & \ldots & \ldots & \ldots & \ldots & \ldots & \ldots\end{array}$

6. KHANNA, R. K. A New Filarial Worm from a North American Snake...

7. Buckley, J. J. C. Some Helminth Parasites from

Domesticated Animals in Southern Rhodesia ... ...

8. Swales, W. E. On Streplovitella acadia (gen. et sp. nov.).

A New Trematode of the Family Heterophyidæ from the Black Duck (Anas rubripes) $\quad \ldots \quad$... $\quad \ldots \quad$...

\section{Publications of the}

\section{Institute of Agricultural Parasitology}

(LONDON SCHOOL OF HYGIENE AND TROPICAL MEDICINE)

JOURNAL OF HELMINTHOLOGY. Edited by R. T. LEIPER, M.D., D.Sc., F.R.S.

Issued quarterly, or more frequently as occasion demands, for the publication of original communications by the Staff and Associated Workers of the Institute.

Subscription Price 25/- net a volume, post free. Volumes I to $X$ bound in cloth, price $30 /-$ net each, post free.

HELMINTHOLOGICAL ABSTRACTS. Edited by R. T. LEIPER, M.D., D.Sc., F.R.S. With the co-operation of B. G. PETERS, Ph.D., M. J. TRIFFITT, D.Sc., and T. W. M. CAMERON, D.Sc., M.R.C.V.S.

Issued in five parts annually (by arrangement with the Imperial Bureau of Agricultural Parasitology) for the publication of abstracts of original papers on applied helminthology which appear in current periodicals.

\section{Subscription Price $16 / 6$ net a volume, post free. Separate parts, price $4 /$ - each, post free.}

Both publications are obtainable through any bookseller, or direct from the Institute of Agricultural Parasitology, Winches Farm Drive, Hatfield Road, St. Albans, Herts., England. 